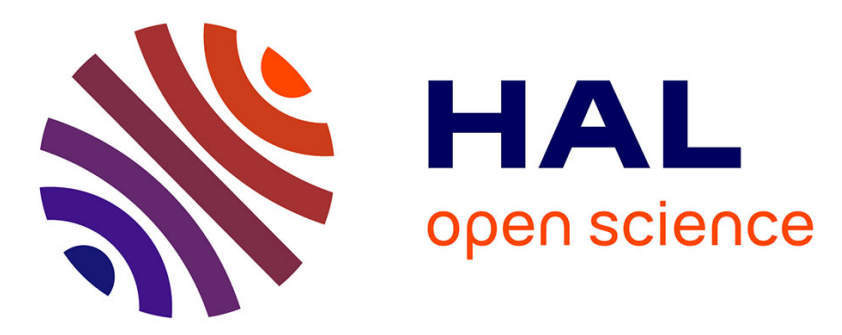

\title{
Case studies of the radical cation reactivity in meso-aryl and octaethyl porphyrins
}

Raphaël Lamare, Laurent Ruhlmann, Romain Ruppert, Jean Weiss

\section{To cite this version:}

Raphaël Lamare, Laurent Ruhlmann, Romain Ruppert, Jean Weiss. Case studies of the radical cation reactivity in meso-aryl and octaethyl porphyrins. Journal of Porphyrins and Phthalocyanines, 2019, 10.1142/S1088424619501980 . hal-02429914

\section{HAL Id: hal-02429914 \\ https://hal.science/hal-02429914}

Submitted on 6 Jan 2020

HAL is a multi-disciplinary open access archive for the deposit and dissemination of scientific research documents, whether they are published or not. The documents may come from teaching and research institutions in France or abroad, or from public or private research centers.
L'archive ouverte pluridisciplinaire $\mathbf{H A L}$, est destinée au dépôt et à la diffusion de documents scientifiques de niveau recherche, publiés ou non, émanant des établissements d'enseignement et de recherche français ou étrangers, des laboratoires publics ou privés. 


\title{
Case studies of the radical cation reactivity in meso-aryl and octaethyl porphyrins
}

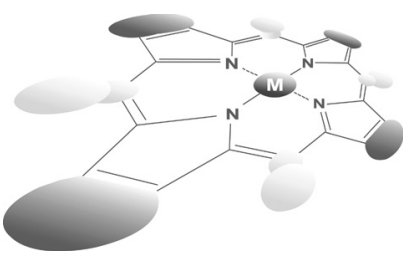

\author{
R. Lamare, L. Ruhlmann, R. Ruppert* and J. Weiss* \\ Institut de Chimie de Strasbourg, UMR 7177 CNRS-Université de Strasbourg, 4 rue Blaise Pascal, \\ 67000 Strasbourg, France
}

Dedicated to Professor Roberto Paolesse on the occasion of his 60th birthday.

Received 8 November 2019

Accepted 9 December 2019

\begin{abstract}
The reactivity of porphyrin radical cationic species derived from octaethyl porphyrin (OEP) or meso-aryl porphyrins with nucleophiles, envisioned as an access route to elaborate porphyrin dimers, has been studied and optimized in the case of OEP. Standardized conditions have been applied to various spacers to show that the success of the reaction is mostly nucleophile dependent and that the method has little chances to yield non-linear bis-porphyrins.
\end{abstract}

KEYWORDS: porphyrins, oxidation, radical cation, nucleophile.

\section{INTRODUCTION}

Along the last decades, the electrophilic reactivity of porphyrin radical cations has established itself as a versatile method to access elaborate porphyrin and multiporphyrin scaffolds. The radical cationic species can undergo two major transformations that are either an oxidative coupling of the radical cation formed to generate a carbon-carbon bond between two porphyrins, or, in the presence of a nucleophile, an addition at the periphery of the porphyrin macrocycle.

The chemical oxidative coupling was used initially by Osuka and co-workers to yield meso-meso linked porphyrin dimers as well as doubly and triply linked dimers $[1,2]$, and the electrochemical version of the coupling has been applied to dimer formation [3]. The process can be iterative and has been used to generate higher oligomers, as powers of 2 , up to porphyrin tapes containing $1024\left(2^{10}\right)$ tetrapyrrolic units. When $\beta$ pyrrolic positions are blocked by ethyl groups, earlier work from

\footnotetext{
${ }^{\square}$ SPP full member in good standing.

*Correspondence to: Institut de Chimie de Strasbourg, UMR 7177 CNRS-Université de Strasbourg, 4 rue Blaise Pascal, 67000 Strasbourg, France; R. Ruppert, email: rruppert@ unistra.fr; J. Weiss, email: jweiss@unistra.fr.
}

Evans and Smith [4] already demonstrated the formation of porphyrin radical cations resulting from the treatment of octaethyl porphyrin (OEP) with thallium(III) nitrate. In the presence of excesses of pyridine or imidazole, it was possible to generate the cationic pyridiniumsubstituted porphyrin $\mathbf{1}$ or the neutral imidazole substituted porphyrin 2 (as represented in Scheme 1). The introduction of anionic nucleophiles or nucleophiles able to lose a proton generates a neutral species (Scheme 2) and significantly reduces the reactivity of the porphyrin macrocycle. In contrast, because the cationic nature of the reaction product sustains the simple addition of a neutral nucleophile, substituted porphyrin radical cations remain reactive and open the way to further reactions such as multiple substitutions or the formation of oligomers.

The electrogeneration of porphyrin radical cations was initiated by Giraudeau et al. [5] using OEP or tetraphenyl porphyrin radical cations in the presence of pyridine, showing that electrosynthesis of pyridinium substituted porphyrins can be performed in high yield. Ruhlmann, Giraudeau and co-workers later demonstrated that by using 4,4'-bipyridine as a nucleophile, bis-porphyrins in various orientations could be obtained [6] and they also extended the electrosynthetic method to phosphiniumbridged bis-porphyrins [7]. This approach has been extensively used by Ruhlmann and co-workers to prepare 


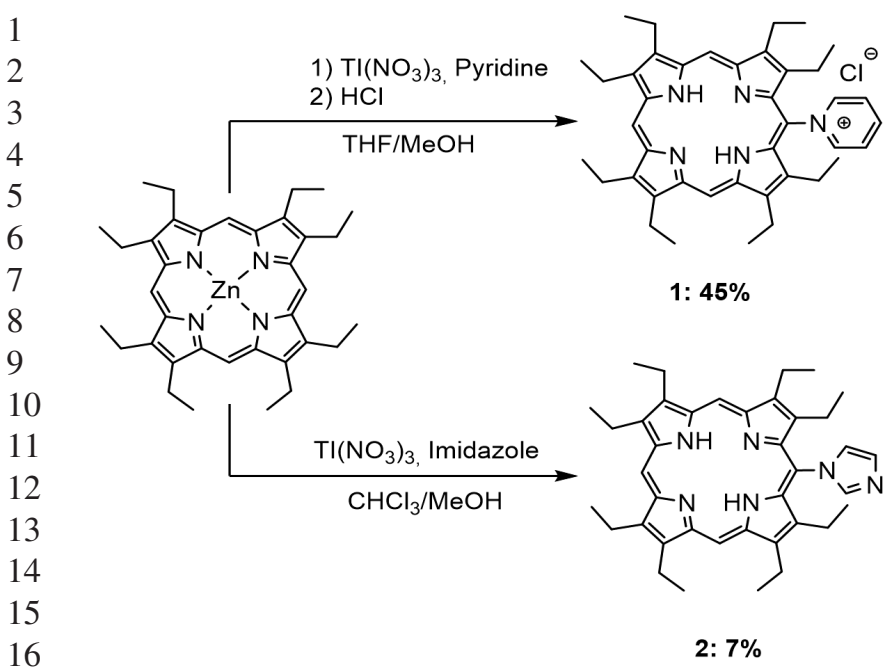

17 Scheme 1. Pioneering work in the reactivity of OEP radical strategies to more elaborated bis-porphyrin, it was (a few monolayers) cannot be easily transferred to the preparation of discrete species in sizable quantities for further synthetic transformations. Thus, a systematic study of the conditions leading to stable cationic adducts on porphyrin radical cations has been performed and is described hereafter. Ultimately, the conditions leading to reproducible preparative scale yields of the desired product have been established.

\section{RESULTS AND DISCUSSION}

In the general mechanism describing the reaction between a triaryl-porphyrin radical cation and a nucleophile (Scheme 3) [9], the clear advantage of electrochemical methods over chemical oxidation [10] is the precise control of the oxidation potential applied for the first oxidation, which enables avoidance of the formation of a dicationic species that can evolve erratically. In the case of polymerization, part of the efficiency of the electro-synthetic approach lies in the absence of a purification step for the polymer that is stuck to the electrode. In these conditions, simple washing can perform the elimination of the supporting electrolyte and soluble starting material. Also, generation of the reactive species at the electrode surface can induce local concentrations of reactive species which with OEP were utilized to generate photocurrents [8].

While investigating the application of similar quickly realized that the efficiency of the method used for the modification of electrodes at a preparative scale

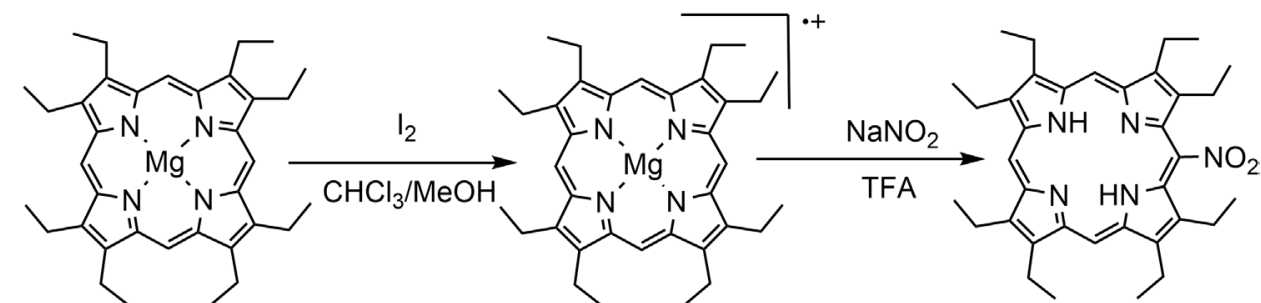

3: $84 \%$

Scheme 2. Alternative oxidation method and addition of an anionic nucleophile

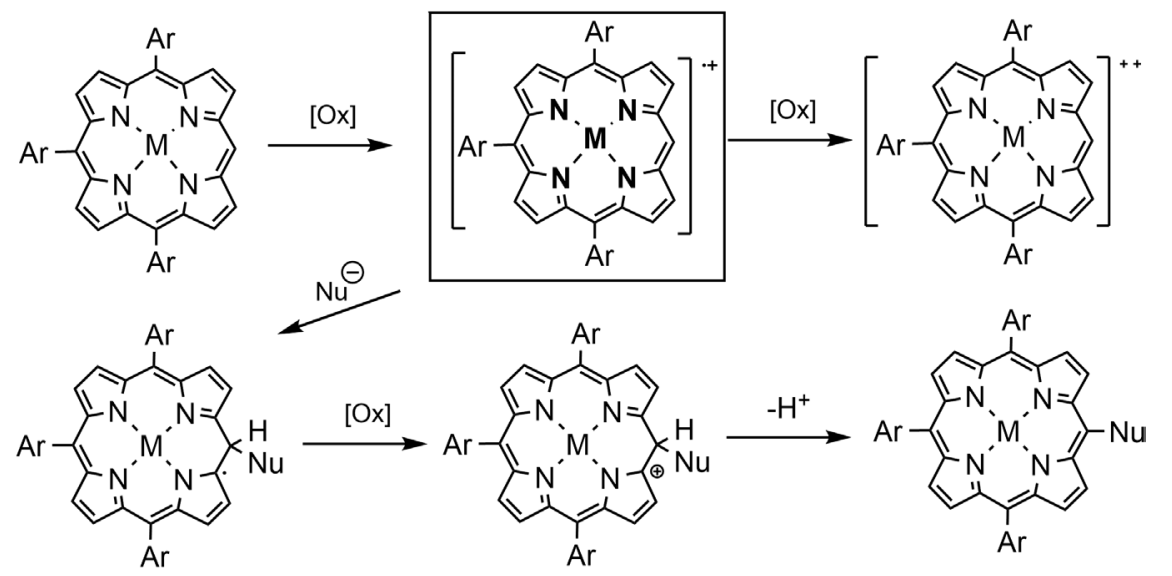

Scheme 3. General reactivity of a triaryl porphyrin radical cation in the presence of a nucleophile 


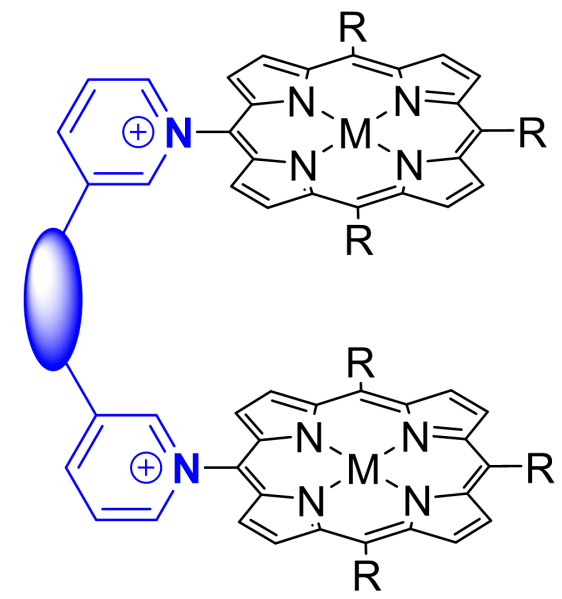

Fig. 1. Targeted bis-porphyrins

are favorable to polymerization. It should be noted that the polymerization is scarcely a problem when OEP derivatives are used unless excesses of oxidant are used or extended electrolysis times are applied.

As starting point of this case study, the general structure of bis-porphyrins, inspired by previous dimer and oligomer formation [11], represented in Fig. 1, was targeted. The purpose of choosing meta pyridyl nucleophiles was to avoid any conjugation between the nucleophiles whenever aryl spacers were used. Triaryl porphyrins have been selected to preclude any kind of oligomerization pathway. Indeed, attempts to prepare such targets by electrosynthetic methods using diaryl porphyrins have always led to the deposition of polymers at the surface of the working electrode. The reaction represented in Scheme 4 has been performed several times and the desired bis-porphyrin species was never observed or even detected. Thus, we opted for a systematic optimization of the preparative chemical approach starting from the $17 \%$ obtained in the usual stoichiometric conditions.

Due to the added value of the starting materials, $4 \mathbf{Z n}$ and di-pyridyl derivatives in Scheme 4, the optimization of the reaction conditions depicted in Fig. 2 (top) was performed on the OEP. Reaction conditions were varied starting from the following conditions: $\mathrm{CH}_{2} \mathrm{Cl}_{2}$ as solvent, 4,4'-bipyridine as nucleophile, lutidine as base, Magic Blue $\left[\left(4-\mathrm{Br}-\mathrm{C}_{6} \mathrm{H}_{4}\right)_{3} \mathrm{~N}\right] \mathrm{SbCl}_{6}$ as oxidant and from 1 to $12 \mathrm{~h}$ of reaction time.

First, to optimize the stoichiometry of Magic Blue required to generate the porphyrin radical cation, a titration was performed on OEP. As shown in Fig. 3, during the titration, the Soret band disappearance around $400 \mathrm{~nm}$ is concomitant to the rise of the reduced Magic Blue strong absorption around $300 \mathrm{~nm}$. At 5 eq of Magic Blue added to the solution, the disappearance of the Soret band is complete. The only change observed when additional oxidative agents are added is the increased absorption band of the Magic Blue. Thus, for all oxidations and for all comparisons of oxidizing agents, a $6 / 1$ oxidant/porphyrin ratio has been utilized.

\section{Influence of the solvent}

Chlorinated organic solvents afforded the highest isolated yield (dichloromethane: $21 \%$ and dichloroethane: $16 \%$ ). In THF and DMF, only traces of the target compound were detected by thin layer chromatography (TLC) analysis of the reaction medium. The solubility of all reagents and products is part of the equation in the efficiency of the reaction and thus, chlorinated organic solvents are suitable for both the neutral and the charged species involved. In contrast, THF is not suitable due to its poor stability $v s$. oxidation and the generation of degradation products concomitant with the consumption of the Magic Blue. Finally, DMF is also known for the formation of radicals in the presence of bases [12] and is thus inappropriate for this reaction.

\section{Influence of the base}

Again, solubility is clearly an issue for the choice of the base but the nucleophilic nature of the base may also play a role and explain the small trend observed when switching from lutidine (21\%) to cesium carbonate $(24 \%)$, and then the incremental decrease through the series $\mathrm{K}_{2} \mathrm{CO}_{3}(19 \%)$ and $\mathrm{Na}_{2} \mathrm{CO}_{3}(7 \%)$.

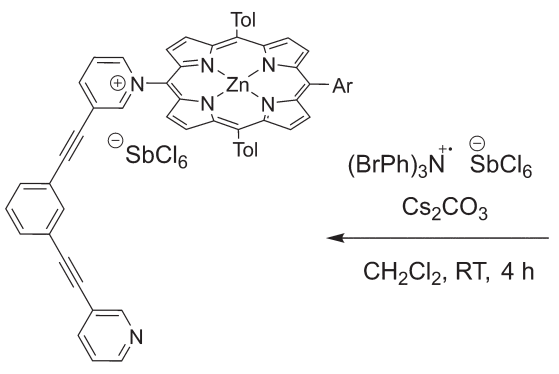

$5 \mathrm{Zn}: 17 \%$
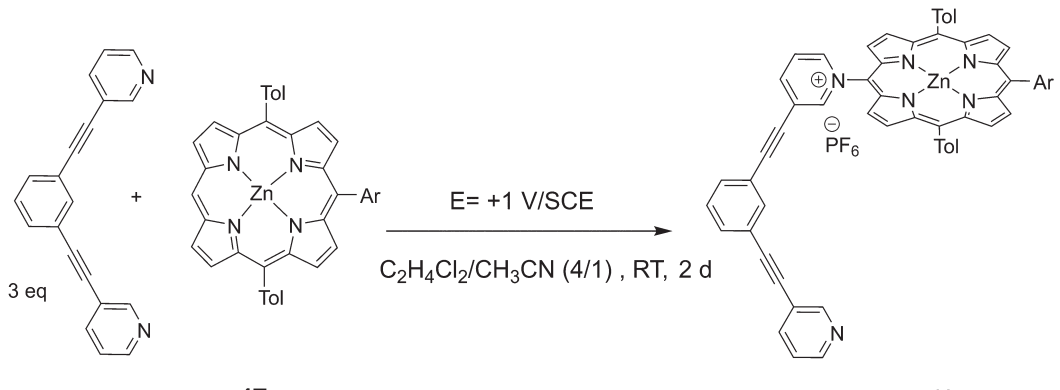

5Zn: $7 \%$

Scheme 4. Standard stoichiometric chemical (left) and electrochemical (right) conditions leading to nucleophilic addition on 


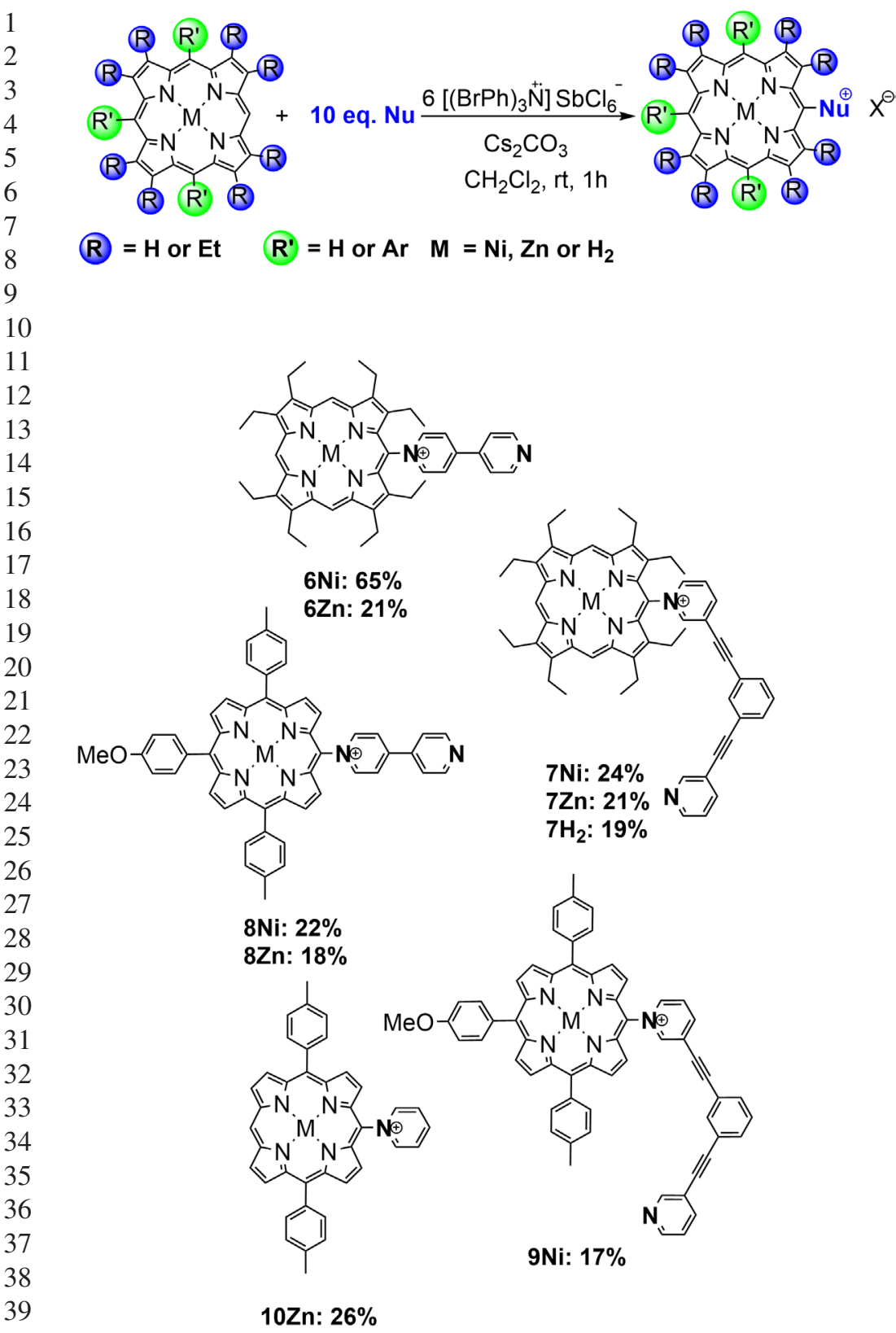

Fig. 2. OEP and tri-arylporphyrin adducts resulting from nucleophilic addition on chemically generated radical cations

\section{Influence of the oxidative agent}

Variations around the oxidative agent very rapidly and clearly showed that the Magic Blue was the only suitable oxidative reagent for this reaction $(24 \%)$, although $\mathrm{NO}^{+}$ salts $\left(\mathrm{SbF}_{6}^{-}\right)$gave significantly better results $(13 \%)$ than dichloro-dicyano-quinone (DDQ: traces), iodosobenzene bis(trifluoroacetate) (PIFA: traces) and $\mathrm{Tl}(\mathrm{III})$ salts (traces).

\section{Reaction time}

Considering the reactive nature of radical species, it also made sense that extending the reaction time would probably not drastically affect the yields. This was confirmed by the quasi constant yield obtained after $1 \mathrm{~h}(23 \%), 4 \mathrm{~h}(24 \%)$, $8 \mathrm{~h}, 12 \mathrm{~h}$ and $24 \mathrm{~h}(21 \%)$. Once the selection of solvents, reagents and reaction time was performed, the final parameter left to be examined was the concentration of the OEP.

\section{Concentration effects}

The last parameter which needed examination was the concentration of the reagents. Intuitively, it is expected that concentration will play an important role when thinking of the existence of the diffusion layer at the surface of the electrode during the electrosynthesis. The success of the latter in the preparation of polymer films and modified electrodes using electro-generated radical cations can be mostly assigned to the high concentration of reactive species in the vicinity of the electrode surface. As a result, the perturbing of the synthesis of discrete molecular species by gradients in the diffusion layer and the increase of polymer byproduct formation is expected. Indeed, this was verified by experiments performed at various concentrations of reagents using standardized reaction conditions: $\mathrm{CH}_{2} \mathrm{Cl}_{2}, \mathrm{Cs}_{2} \mathrm{CO}_{3}$ (6 eq), Magic Blue (6 eq) for $1 \mathrm{~h}$. Rather concentrated mixtures of 16 and $1 \mathrm{mM}$ led respectively to yields of 19 and $24 \%$, whereas dilution to $0.1 \mathrm{mM}$ and $6 \times 10^{-2} \mathrm{mM}$ yielded 39 and $65 \%$ of the desired compound.

With these optimized conditions in hand, a series of reactions with OEP and tri-aryl porphyrins have been performed and led to reproducible results, although moderate yields of the porphyrin adduct were obtained in most cases. The compounds obtained are summarized in Fig. 2. Comparing the yields obtained for the preparation of $\mathbf{6 N i}$ and $\mathbf{8 N i}(65 \%$ vs. $22 \%)$, it should be emphasized that in the case of triarylporphyrins the main product of the reaction was always the undesired dimer resulting from the homocoupling of the generated porphyrin radical cation. This was described earlier for electrochemical oxidations and explains the low yield observed for the preparation of $\mathbf{8 N i}$ [13, 14].

Immediately, it can be clearly established that the optimized conditions for $\mathbf{6 N i}$ cannot be extended to other adducts but the comparison with yields obtained by electrochemistry is always in favor of the chemical synthesis as long as the preparative scale is concerned. 


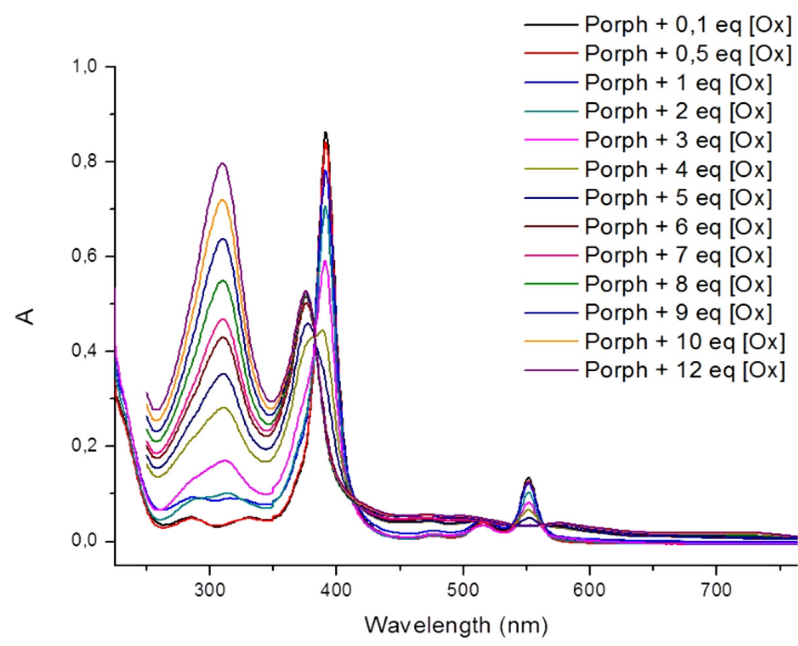

Fig. 3. Titration of OEP with Magic Blue $\left(\left[\left(4-\mathrm{Br}^{-} \mathrm{C}_{6} \mathrm{H}_{4}\right)_{3} \mathrm{~N}\right]\right.$ $\mathrm{SbCl}_{6}$ ) in $\mathrm{CH}_{2} \mathrm{Cl}_{2}$ at room temperature

However, the trends observable in standardized conditions give a few indications on how to improve the preparative use of porphyrin radical cations. The drastic drop in the yield from $6 \mathrm{Ni}$ to $6 \mathrm{Zn}$ is clearly indicative of the general trend of nickel porphyrin always giving better yields and cleaner reactions. It can be partially explained by the low affinity of Ni-porphyrins for $N$ containing axial ligands, thus, there are no binding events competing with the nucleophile reactivity. Also handling of the reaction mixtures with nickel porphyrins is facilitated by the absence of aggregates and self-assembled species during the purification processes. In the standardized conditions, the nucleophilicity of the pyridine group does not influence much the yield of the adduct formation. The comparison of the yields in the case of all OEPNi adducts suggests that short bidentates like $4,4^{\prime}$-bipyridine in $\mathbf{6 N i}$ are more efficient than widely spaced bidentates This may be due to the proximity of both nucleophilic nitrogen atoms and enriching electronic effects stronger in 4,2'-bipyridine than in extended bis-pyridine nucleophiles (7-9M) or in an isolated pyridine (10Zn). Steric hindrance differences between OEP and meso-arylporphyrins do not affect the outcome of the nucleophilic additions either.

However, these results clearly show that whereas an extended use of the reactivity of porphyrin radical cations has been made over the last decades for the generation of modified electrodes of linear dimers, application of such method at the preparative scale to obtain other multiporphyrins, such as porphyrin tweezers will require systematic studies of the reaction conditions. This work has shown that discrete species can be obtained with reasonable yield in optimized conditions for porphyrinpyridinium-pyridyl adducts but that the use of other nucleophiles will require case-by-case adaptation of the reaction conditions. At this stage of development this approach does not seem to be suitable for the synthesis of porphyrin tweezers.
EXPERIMENTAL

\section{General methods}

Solvents used for the reactions or column chromatography were distilled from sodium/benzophenone ketyl (tetrahydrofuran, toluene) or calcium hydride (dichloromethane). All other commercially available reagents and solvents were used without further purification. Bases $\left(\mathrm{K}_{3} \mathrm{PO}_{4}, \mathrm{~K}_{2} \mathrm{CO}_{3}, \mathrm{Cs}_{2} \mathrm{CO}_{3}\right.$ and $\left.\mathrm{Na}_{2} \mathrm{CO}_{3}\right)$ were oven-dried at $100^{\circ} \mathrm{C}$. Analytical thin layer chromatography (TLC) was carried out on silica gel $60 \mathrm{~F}_{254}$ (Merck) and column chromatography was performed with silica gel or alumina from Merck (alumina oxide 60 standardized or silica gel 60, 0.04-0.063 $\mu \mathrm{m}$ ). Nuclear magnetic resonance spectra of the proton $\left({ }^{1} \mathrm{H}\right.$ NMR), carbon $\left({ }^{13} \mathrm{C}\right.$ NMR $)$ and $2 \mathrm{D}\left({ }^{1} \mathrm{H}-{ }^{1} \mathrm{H}\right.$ COSY and NOESY $)$ were recorded on Bruker Advance spectrometers at 300, 400 or $500 \mathrm{MHz}$. The chemical shifts are given in partsper-million $(\mathrm{ppm})$ on the delta $(\delta)$ scale. The solvent peak was used as reference value: for ${ }^{1} \mathrm{H}$ NMR: $\mathrm{CDCl}_{3}=7.26$ ppm, DMSO- $d_{6}=2.50 \mathrm{ppm}$, for ${ }^{13} \mathrm{C}$ NMR: $\mathrm{CDCl}_{3}=77.23$ ppm, DMSO- $d_{6}=39.52 \mathrm{ppm}$. The data are presented as follows: chemical shift, multiplicity $(s=$ singlet, $d=$ doublet, $t=$ triplet, $q=$ quadruplet, $h=$ heptuplet, $m=$ multiplet), coupling constant $(\mathrm{J} / \mathrm{Hz})$ and the integration. Mass spectra were obtained by ESI-TOF or MALDI-TOF (337 $\mathrm{nm}$ nitrogen laser for desorption, dithranol used as matrix) experiments. High resolution mass spectra (HRMS) data were recorded on a microTOF spectrometer equipped with orthogonal electrospray interface (ESI). The ions $(\mathrm{m} / \mathrm{z})$ were analyzed on a Bruker Daltonics microTOF for ESI and a Bruker Autoflex II TOF-TOF for MALDI. The parent ions, $[\mathrm{M}+\mathrm{H}]^{+},[\mathrm{M}+\mathrm{K}]^{+},[\mathrm{M}+$ $\mathrm{Na}]^{+}$or $\left[\mathrm{M}^{\mathrm{n}+}\right]$ are given. UV-vis spectra were recorded on a Cary 5000 UV/vis/NIR double-beam spectrometer in dichloromethane or chloroform. Extinction coefficients were determined for samples with sample concentrations ranging from $5 \cdot 10^{-6}$ to $5 \cdot 10^{-5}$ mol. $\mathrm{L}^{-1}$.

The following compounds were prepared as described in the literature: 5,15-bis(p-tolyl)porphyrin [15-17] from $2,2^{\prime}$-dipyrromethane and $p$-tolualdehyde [18], 10-(4methoxy-phenyl)-5,15-di-p-tolylporphyrin [19], octaethylporphyrin [20], [5,15-bis(p-tolyl)porphyrinato]-zinc [15], 10-(4-methoxyphenyl)-5,15-di-p-tolylporphyrin-zinc [21], octaethyl-porphyrin-zinc [22], octaethyl-porphyrinnickel (S) [22] and octaethyl-porphyrin-palladium [23].

\section{General procedure for the oxidation reaction (GP1)}

A solution of oxidant in dry DCM $(200 \mathrm{~mL})$ was degassed under vacuum at $-78^{\circ} \mathrm{C}$ and added dropwise by cannula to a stirred solution of porphyrin (1 eq), cesium carbonate (10 eq) and nucleophile in DCM at room temperature. The mixture was stirred for $1 \mathrm{~h}$ under argon. Water was added to the reaction mixture. The organic layer was separated, and the aqueous layer was extracted 
with DCM $(20 \mathrm{~mL})$. The combined organic layers were washed with water, dried over $\mathrm{Na}_{2} \mathrm{SO}_{4}$, filtered and the solvent was removed under vacuum.

Zn-porph-bisPy+ (5Zn). Prepared following the procedure for GP1 and using tris(4-bromophenyl) ammoniumyl hexachloroantimonate $(78 \mathrm{mg}, 0.096 \mathrm{mmol}$, 1.2 eq), 10-(4-methoxyphenyl)-5,15-di-p-tolylporphyrinzinc (50 mg, $0.08 \mathrm{mmol}, 1 \mathrm{eq})$, cesium carbonate $(160 \mathrm{mg}$, $0.8 \mathrm{mmol}, 10 \mathrm{eq})$ and 1,3-bis(pyridin-3-ylethynyl) benzene (224 mg, $0.8 \mathrm{mmol}, 10 \mathrm{eq})$. The crude product was purified by silica gel column chromatography (DCM and gradually ending with DCM/MeOH 9/1). The compound 5Zn (15 mg, $0.012 \mathrm{mmol}, 17 \%)$ was obtained as a red solid. ${ }^{1} \mathrm{H}$ NMR $(400 \mathrm{MHz}$, Chloroform- $d$ ). $\delta 9.54$ $\left(\mathrm{d}, J=5.8 \mathrm{~Hz}, 1 \mathrm{H}, \mathrm{H}-\mathrm{py}^{+}\right), 9.41\left(\mathrm{~s}, 1 \mathrm{H}, \mathrm{H}-\mathrm{py}^{+}\right), 9.22(\mathrm{~d}$, $J=5.0 \mathrm{~Hz}, 2 \mathrm{H}, \mathrm{H}-\beta$-pyrrolic), 9.15 (d, $J=5.8 \mathrm{~Hz}, 1 \mathrm{H}$, H-py ${ }^{+}$), 9.09 (s, 4H, H- $\beta$-pyrrolic), 8.88 (br, 1H, H-py), 8.75 (d, J = 5.0 Hz, 2H, H- $\beta$-pyrrolic), 8.68 (s, 2H, H-py ${ }^{+}$ and, H-py), 7.90 (d, $J=8.2 \mathrm{~Hz}, 2 \mathrm{H}$, H-ortho-anis), 7.84 (d, $J=7.7 \mathrm{~Hz}, 4 \mathrm{H}$, H-ortho-tolyl), $7.80(\mathrm{~d}, J=7.9 \mathrm{~Hz}$, 8H), 7.71-7.69 (m, 4H, H-py), 7.69-7.62 (m, 2H, H-py and $\mathrm{H}$-aryl), $7.52(\mathrm{~m}, 2 \mathrm{H}, \mathrm{H}$-aryl), 7.47 (d, $J=7.7 \mathrm{~Hz}$, 4H, H-ortho-tolyl), 7.39-7.31 (m, 1H, H-aryl), 7.23 (d, $J=8.2 \mathrm{~Hz}, 2 \mathrm{H}, \mathrm{H}$-ortho-anis), 4.05 (s, 3H, $-\mathrm{OCH}_{3}$ ), 2.61 $\left(\mathrm{s}, 6 \mathrm{H},-\mathrm{CH}_{3}\right) .{ }^{13} \mathrm{C}$ NMR $\left(126 \mathrm{MHz}, \mathrm{DMSO}-d_{6}\right) . \delta 159.9$, $152.4,152.4,152.1,151.1,150.4,150.0,149.9,149.8$, $149.7,146.0,143.2,142.3,141.8,139.1,138.4,136.5$, $135.4,135.1,134.1,133.7,132.7,132.5,131.6,130.4$, $128.5,127.6,124.3,123.1,123.1,123.0,122.9,122.1$, 121.6, 119.4, 118.1, 113.3, 95.8, 91.2, 87.8, 84.4, 55.9, 21.5. UV-vis (DMSO): $\lambda(\varepsilon)=418$ (87000), 534 (5600), $566 \mathrm{~nm}\left(3600 \mathrm{M}^{-1} \cdot \mathrm{cm}^{-1}\right)$. ESI-TOF: $\mathrm{m} / \mathrm{z}=939.42$. Calcd for $\mathrm{C}_{61} \mathrm{H}_{41} \mathrm{~N}_{6} \mathrm{ZnO}^{+}\left(\left[\mathrm{M}^{+}\right]\right)$: 939.45. TLC (silica) $R f: 0.18$ (DCM/MeOH 9/1).

$\mathrm{Ni}-\mathrm{OEP}-\mathrm{biPy}^{+}(\mathbf{6 N i})$. Prepared following the procedure for GP1 and using tris(4-bromophenyl) ammoniumyl hexachloroantimonate (208 $\mathrm{mg}$, $0.256 \mathrm{mmol}, 6 \mathrm{eq}$ ), octaethylporphyrin-nickel (26 mg, $0.0423 \mathrm{mmol}, 1 \mathrm{eq})$, cesium carbonate $(90 \mathrm{mg}$, $0.423 \mathrm{mmol}, 10 \mathrm{eq}$ ) and bipyridine ( $66 \mathrm{mg}, 0.254 \mathrm{mmol}$, $10 \mathrm{eq})$. The crude product was purified by silica gel column chromatography (DCM and gradually ending with $\mathrm{DCM} / \mathrm{MeOH} 9 / 1$ ). The compound 6Ni (24 mg, $0.028 \mathrm{mmol}, 65 \%$ ) was obtained as a purple solid after recrystallization (addition of saturated $\mathrm{KPF}_{6}$ aqueous solution to acetone solution). ${ }^{1} \mathrm{H}$ NMR (500 MHz, DMSO- $\left.d_{6}\right): \delta 10.61\left(\mathrm{~d}, J=6.8 \mathrm{~Hz}, 2 \mathrm{H}, \mathrm{H}\right.$-ortho-pyr ${ }^{+}$), 9.92 (s, 2H, H-meso), 9.87 (s, 1H, H-meso), 9.23 (d, $J=$ $6.8 \mathrm{~Hz}, 2 \mathrm{H}, \mathrm{H}-$ meta-pyr $^{+}$), 9.20-9.02 (m, 2H, H-orthopyr), 8.50 (br, 2H, H-meta-pyr), 4.07-3.79 (m, 12H, $\left.-\mathrm{CH}_{2^{-}}\right), 2.36\left(\mathrm{q}, J=7.7 \mathrm{~Hz}, 4 \mathrm{H},-\mathrm{CH}_{2}-\right), 1.82-1.66(\mathrm{~m}$, $\left.18 \mathrm{H},-\mathrm{CH}_{3}\right), 1.19-1.10\left(\mathrm{~m}, 6 \mathrm{H},-\mathrm{CH}_{3}\right) .{ }^{13} \mathrm{C}$ NMR (126 $\left.\mathrm{MHz}, \mathrm{DMSO}-d_{6}\right): \delta 208.4,206.5,156.0,151.0,148.1$, $145.6,145.3,142.0,141.7,141.4,140.1,135.7,124.4$, $117.6,98.5,98.2,68.5,55.8,32.1,30.7,29.6,20.5$, $18.4,18.3 .{ }^{31} \mathrm{P}$ NMR $\left(203 \mathrm{MHz}, \mathrm{DMSO}-d_{6}\right): \delta-143.9(\mathrm{~h}$, $J=708 \mathrm{~Hz}) .{ }^{19} \mathrm{~F}$ NMR $\left(471 \mathrm{MHz}, \mathrm{DMSO}-d_{6}\right): \delta-70.1$ (d, $J=708 \mathrm{~Hz})$. UV-vis $\left(\mathrm{CHCl}_{3}\right): \lambda(\varepsilon)=401$ (79000), 528 (8700), $563 \mathrm{~nm}\left(12000 \mathrm{M}^{-1} \cdot \mathrm{cm}^{-1}\right)$. ESI-TOF: $m / z=745.35$ Calcd for $\mathrm{C}_{46} \mathrm{H}_{51} \mathrm{~N}_{6} \mathrm{Ni}^{+}\left(\left[\mathrm{M}^{+}\right]\right): 745.35$ TLC (silica): $R_{f}: 0.36$ (DCM/MeOH 9/1).

$\mathbf{Z n - O E P - b i P y ^ { + }}(\mathbf{6 Z n})$. Prepared following the procedure for GP1 and using tris(4-bromophenyl) ammoniumyl hexachloroantimonate $(81 \mathrm{mg}, 0.10 \mathrm{mmol}$, $1.2 \mathrm{eq})$, octaethylporphyrin-zinc $(50 \mathrm{mg}, 0.083 \mathrm{mmol}$, $1 \mathrm{eq})$, cesium carbonate $(176 \mathrm{mg}, 0.83 \mathrm{mmol}, 10 \mathrm{eq})$ and bipyridine (326 mg, $1.9 \mathrm{mmol}, 25 \mathrm{eq}$ ). The crude product was purified by silica gel column chromatography (DCM and gradually ending with DCM/MeOH 9/1). The compound 6Zn (19 mg, $0.017 \mathrm{mmol}, 21 \%)$ was obtained as a purple solid. ${ }^{1} \mathrm{H}$ NMR $\left(500 \mathrm{MHz}, \mathrm{DMSO}-d_{6}\right): \delta$ 10.74 (d, $J=6.2 \mathrm{~Hz}, 2 \mathrm{H}, \mathrm{H}$-ortho-pyr ${ }^{+}$), 10.25 (s, 2H, H-meso), 10.19 (s, 1H, H-meso), 9.21 (d, $J=6.2 \mathrm{~Hz}$, $2 \mathrm{H}, \mathrm{H}-$ meta-pyr $\left.{ }^{+}\right), 9.06$ (d, J = 6.4 Hz, 2H, H-ortho-pyr), 8.52 (d, J = 6.4 Hz, 2H, H-meta-pyr), 4.22-3.86 (m, 12H, $\left.-\mathrm{CH}_{2}{ }^{-}\right), 2.45\left(\mathrm{q}, J=7.5 \mathrm{~Hz}, 4 \mathrm{H},-\mathrm{CH}_{2}-\right), 1.96-1.80(\mathrm{~m}$, $\left.16 \mathrm{H},-\mathrm{CH}_{3}\right), 1.33\left(\mathrm{t}, J=7.5 \mathrm{~Hz}, 6 \mathrm{H},-\mathrm{CH}_{3}\right) \cdot{ }^{13} \mathrm{C} \mathrm{NMR}$ $\left(126 \mathrm{MHz}, \mathrm{DMSO}-d_{6}\right): \delta 155.9,151.7,150.9,149.0$, $148.5,147.0,146.8,145.3,143.9,143.6,143.4,142.1$, $140.9,140.1,124.4,124.2,123.1,121.7,120.9,118.7$, 99.3, 99.1, 20.7, 19.8, 19.5, 19.5, 19.4, 19.4, 19.2. UV-vis $\left(\mathrm{CHCl}_{3}\right): \lambda(\varepsilon)=344$ (18500), 419 (97500), 547 (9700), $581 \mathrm{~nm}\left(8700 \mathrm{M}^{-1} \cdot \mathrm{cm}^{-1}\right)$. ESI-TOF: $\mathrm{m} / \mathrm{z}=751.34$. Calcd for $\mathrm{C}_{46} \mathrm{H}_{51} \mathrm{~N}_{6} \mathrm{Zn}^{+}\left(\left[\mathrm{M}^{+}\right]\right)$: 751.35. TLC (silica) $R_{f}: 0.20$ (DCM/MeOH 9/1).

Ni-OEP-bisPy ${ }^{+}$(7Ni). Prepared following the procedure for GP1 and using tris(4-bromophenyl)ammoniumyl hexachloroantimonate $(208 \mathrm{mg}, 0.256 \mathrm{mmol}$, $6 \mathrm{eq}$ ), octaethylporphyrin-nickel (25 mg, $0.042 \mathrm{mmol}$, $1 \mathrm{eq}$ ), cesium carbonate ( $90 \mathrm{mg}, 0.423 \mathrm{mmol}, 10 \mathrm{eq}$ ) and 1,3-bis(pyridin-3-ylethynyl)benzene (118 mg, $0.423 \mathrm{mmol}, 10 \mathrm{eq})$. The crude product was purified by silica gel column chromatography (DCM and gradually ending with $\mathrm{DCM} / \mathrm{MeOH}$ 9/1). The compound $7 \mathrm{Ni}$ (10 mg, $0.010 \mathrm{mmol}, 24 \%$ ) was obtained as a red solid after recrystallization (addition of saturated $\mathrm{KPF}_{6}$ aqueous solution to acetone solution). ${ }^{1} \mathrm{H}$ NMR $\left(500 \mathrm{MHz}, \mathrm{DMSO}-d_{6}\right): \delta 11.15$ (s, 1H, H-pyr $\left.{ }^{+}\right), 10.44$ (dt, $J=5.9,1.4 \mathrm{~Hz}, 1 \mathrm{H}, \mathrm{H}-\mathrm{pyr}^{+}$), 10.22 (s, 2H, H-meso), 10.15 (s, 1H, H-meso), 9.51 (dt, $J=8.4,1.4 \mathrm{~Hz}, 1 \mathrm{H}$, $\mathrm{Hpyr}^{+}$), 8.73 (dd, $\left.J=8.4,5.9 \mathrm{~Hz}, 1 \mathrm{H}, \mathrm{H}-\mathrm{pyr}^{+}\right)$, 8.66-8.63 (m, 1H, H-pyr), 8.50 (dd, $J=4.9,1.7 \mathrm{~Hz}, 1 \mathrm{H}, \mathrm{H}-\mathrm{pyr}$ ), 7.88 (m, 2H, H-pyr and H-aryl), 7.70 (tt, $J=7.4,1.4 \mathrm{~Hz}$, 2H, H-aryl), 7.54 (t, $J=7.4 \mathrm{~Hz}, 1 \mathrm{H}, \mathrm{H}$-aryl), 7.38 (ddd, $J=7.4,4.9,1.7 \mathrm{~Hz}, 1 \mathrm{H}, \mathrm{H}-\mathrm{pyr}), 4.18-3.88$ (m, 12H, $\left.-\mathrm{CH}_{2}-\right), 2.58-2.49\left(\mathrm{~m}, 2 \mathrm{H},-\mathrm{CH}_{2}-\right), 2.30-2.18(\mathrm{~m}, 2 \mathrm{H}$, $\left.-\mathrm{CH}_{2}-\right), 1.92-1.71\left(\mathrm{~m}, 18 \mathrm{H},-\mathrm{CH}_{3}\right), 1.33(\mathrm{t}, J=7.4 \mathrm{~Hz}$, $\left.6 \mathrm{H},-\mathrm{CH}_{3}\right) .{ }^{13} \mathrm{C}$ NMR $\left(126 \mathrm{MHz}, \mathrm{DMSO}-d_{6}\right): \delta 152.4$, $151.6,150.0,149.2,148.5,148.1,146.7,146.3,143.6$, $143.2,141.4,139.4,138.6,134.8,133.3,132.3,132.0$, $129.8,126.9,123.6,122.5,121.7,120.9,118.8,118.1$, $98.9,98.7,98.4,96.4,90.6,87.2,83.2,30.6,20.2,19.1$, $19.0,19.0,19.0,18.9,18.9,18.8$. UV-vis $\left(\mathrm{CHCl}_{3}\right): \lambda(\varepsilon)=$ 403 (89500), 527 (13600), $565 \mathrm{~nm}\left(18300 \mathrm{M}^{-1} \cdot \mathrm{cm}^{-1}\right)$. 
MALDI-TOF: $m / z=869.453$ Calcd for $\mathrm{C}_{56} \mathrm{H}_{55} \mathrm{~N}_{6} \mathrm{Ni}^{+}$ ([M $\left.{ }^{+}\right]$): 869.38. TLC (silica) $R_{f}: 0.16$ (DCM/MeOH 9/1).

Zn-OEP-bisPy ${ }^{+} \quad(\mathbf{Z n})$. Prepared following the procedure for GP1 and using tris(4-bromophenyl)ammoniumyl hexachloroantimonate (40 $\mathrm{mg}, 0.049 \mathrm{mmol}$, $1.2 \mathrm{eq}$ ), octaethylporphyrin-zinc $(25 \mathrm{mg}, 0.041 \mathrm{mmol}$, $1 \mathrm{eq})$, cesium carbonate $(87 \mathrm{mg}, 0.41 \mathrm{mmol}, 10 \mathrm{eq})$ and 1,3-bis(pyridin-3-ylethynyl)benzene (22 mg, $1.9 \mathrm{mmol}$, 2 eq). The crude product was purified by silica gel column chromatography (DCM and gradually ending with DCM/ $\mathrm{MeOH}$ 9/1). The compound 7Zn (10 mg, $0.008 \mathrm{mmol}$, $21 \%)$ was obtained as a red solid. ${ }^{1} \mathrm{H}$ NMR $(500 \mathrm{MHz}$, DMSO- $d_{6}$ ): $\delta 11.20$ (s, 1H, H-pyr $\left.{ }^{+}\right), 10.49$ (dt, $J=5.9$, $1.4 \mathrm{~Hz}, 1 \mathrm{H}, \mathrm{H}-\mathrm{pyr}^{+}$), 10.27 (s, 2H, H-meso), 10.20 (s, $1 \mathrm{H}, \mathrm{H}-m e s o), 9.56\left(\mathrm{dt}, J=8.3,1.4 \mathrm{~Hz}, 1 \mathrm{H}, \mathrm{H}_{-} \mathrm{pyr}^{+}\right.$), $8.78\left(\mathrm{dd}, J=8.3,5.9 \mathrm{~Hz}, 1 \mathrm{H}, \mathrm{H}-\mathrm{pyr}^{+}\right.$), 8.71-8.68 (m, 1H, H-pyr), 8.55 (dd, $J=4.9,1.7 \mathrm{~Hz}, 1 \mathrm{H}, \mathrm{H}-\mathrm{pyr}), 7.93$ (m, 2H, H-pyr and H-aryl), 7.75 (tt, $J=7.4,1.4 \mathrm{~Hz}, 2 \mathrm{H}$, $\mathrm{H}$-aryl), 7.59 (t, $J=7.4 \mathrm{~Hz}, 1 \mathrm{H}, \mathrm{H}$-aryl), 7.43 (ddd, $J=$ 7.9, 4.9, $1.7 \mathrm{~Hz}, 1 \mathrm{H}, \mathrm{H}-\mathrm{pyr}), 4.23-3.93\left(\mathrm{~m}, 12 \mathrm{H},-\mathrm{CH}_{2}-\right)$, 2.63-2.54 (m, 2H, - $\left.\mathrm{CH}_{2^{-}}\right), 2.35-2.23\left(\mathrm{~m}, 2 \mathrm{H},-\mathrm{CH}_{2^{-}}\right)$, $1.97-1.76\left(\mathrm{~m}, 18 \mathrm{H},-\mathrm{CH}_{3}\right), 1.38(\mathrm{t}, J=7.4 \mathrm{~Hz}, 6 \mathrm{H}$, $\left.-\mathrm{CH}_{3}\right) \cdot{ }^{13} \mathrm{C}$ NMR $\left(126 \mathrm{MHz}, \mathrm{DMSO}-d_{6}\right): \delta 152.4,151.6$, 150.0, 149.3, 148.6, 148.1, 146.8, 146.4, 143.6, 143.3, $141.4,139.5,138.6,134.9,133.3,132.4,132.0,129.9$, $126.9,123.7,122.6,121.8,121.0,118.8,118.2$, 98.9, $98.8,98.5,96.4,90.7,87.3,83.2,30.7,20.2,19.2$, $19.1,19.1,19.05,19.0,18.9,18.8$. UV-vis $\left(\mathrm{CHCl}_{3}\right): \lambda$ $(\varepsilon)=341$ (26300), 417 (85900), 549 (11400), $584 \mathrm{~nm}$ $\left(11100 \mathrm{M}^{-1} \cdot \mathrm{cm}^{-1}\right)$. ESI-TOF: $\mathrm{m} / \mathrm{z}=875.39$. Calcd for $\mathrm{C}_{56} \mathrm{H}_{55} \mathrm{~N}_{6} \mathrm{Zn}^{+}\left(\left[\mathrm{M}^{+}\right]\right): 875.38$. TLC (silica) $R_{f}: 0.17$ (DCM/MeOH 9/1).

Free-base OEP-bisPy ${ }^{+}\left(\mathbf{7 H}_{2}\right)$. Prepared following the procedure for GP1 and using tris(4-bromophenyl)ammoniumyl hexachloroantimonate $(229 \mathrm{mg}, 0.280 \mathrm{mmol}$, $6 \mathrm{eq}$ ), octaethylporphyrin-nickel (25 mg, $0.046 \mathrm{mmol}$, $1 \mathrm{eq})$, cesium carbonate (97 mg, $0.46 \mathrm{mmol}, 10 \mathrm{eq})$ and 1,3-bis(pyridin-3-ylethynyl)benzene (129 mg, $0.46 \mathrm{mmol}, 10 \mathrm{eq})$. The crude product was purified by silica gel column chromatography (DCM and gradually ending with $\mathrm{DCM} / \mathrm{MeOH}$ 9/1). The compound $\mathbf{7} \mathbf{H}_{\mathbf{2}}$ (8 mg, $0.087 \mathrm{mmol}, 19 \%$ ) was obtained as a red solid after recrystallization (addition of saturated $\mathrm{KPF}_{6}$ aqueous solution to acetone solution). ${ }^{1} \mathrm{H}$ NMR $(500 \mathrm{MHz}$, DMSO- $\left.d_{6}\right): \delta 11.21$ (d, $\left.J=1.7 \mathrm{~Hz}, 1 \mathrm{H}, \mathrm{H}-\mathrm{py}^{+}\right), 10.69$ 10.60 (m, 1H, H-py ${ }^{+}$), 10.44 (s, 2H, H-meso), 10.36 (s, 1H, H-meso), 9.65-9.56 (m, 1H, H-pyr ${ }^{+}$), 8.87 (dd, $\left.J=8.4,5.9 \mathrm{~Hz}, 1 \mathrm{H}, \mathrm{H}-\mathrm{pyr}^{+}\right), 8.71(\mathrm{dd}, J=1.7,0.9 \mathrm{~Hz}$, 1H, H-py), 8.56 (dd, $J=4.9,1.7 \mathrm{~Hz}, 1 \mathrm{H}, \mathrm{H}-\mathrm{pyr}$ ), 7.97-7.89 (m, 2H, H-py and H-aryl), 7.74 (dd, $J=$ 7.8, $1.7 \mathrm{~Hz}, 2 \mathrm{H}, \mathrm{H}$-aryl), 7.62-7.56 (m, 1H, H-aryl), 7.44-7.41 (m, 1H, H-pyr), 4.15 (h, J=7.5 Hz, $12 \mathrm{H},-\mathrm{CH}_{2^{-}}$), 2.63-2.56 (m, 2H, - $\left.\mathrm{CH}_{2}-\right), 2.42\left(\mathrm{~m}, 2 \mathrm{H},-\mathrm{CH}_{2^{-}}\right), 1.87$ $\left(\mathrm{m}, 16 \mathrm{H},-\mathrm{CH}_{3}\right), 1.39\left(\mathrm{t}, J=7.5 \mathrm{~Hz}, 6 \mathrm{H},-\mathrm{CH}_{3}\right),-3.62$ (d, $J=10.2 \mathrm{~Hz}, 2 \mathrm{H}$, free base). DEPT ${ }^{13} \mathrm{C}$ NMR (126 $\left.\mathrm{MHz}, \mathrm{DMSO}-d_{6}\right)$ : $\delta 152.2,151.4,149.1,138.4,134.6$, $133.1,132.1,129.6,127.2,123.4,100.0,98.7,98.5,19.7$,
$18.7,18.6,18.4,18.3 .{ }^{31} \mathrm{P}$ NMR $\left(203 \mathrm{MHz}, \mathrm{DMSO}-d_{6}\right): \delta$ -143.9 (h, $J=708 \mathrm{~Hz}) .{ }^{19} \mathrm{~F}$ NMR (471 MHz, DMSO- $\left.d_{6}\right)$ : $\delta-70.1(\mathrm{~d}, J=708 \mathrm{~Hz})$. UV-vis $(\mathrm{DCM}): \lambda(\varepsilon)=407$ (84800), 509 (13000), 542 (8900), 574 (7900), $626 \mathrm{~nm}$ $\left(6100 \mathrm{M}^{-1} \cdot \mathrm{cm}^{-1}\right)$. MALDI-TOF: $\mathrm{m} / \mathrm{z}=813.47 \mathrm{Calcd}$ for $\mathrm{C}_{56} \mathrm{H}_{57} \mathrm{~N}_{6}^{+}\left(\left[\mathrm{M}^{+}\right]\right): 813.46$. TLC (silica) $R_{f} 0.18$ (DCM/ $\mathrm{MeOH}$ 9/1).

Ni-Porph-biPy ${ }^{+}$(8Ni). Prepared following the procedure for GP1 and using tris(4-bromophenyl) ammoniumyl hexachloroantimonate $(73 \mathrm{mg}, 0.09 \mathrm{mmol}$, $1.2 \mathrm{eq}), 10$-(4-methoxyphenyl)-5,15-di-p-tolylporphyrinnickel $(50 \mathrm{mg}, 0.08 \mathrm{mmol}, 1 \mathrm{eq}$ ), cesium carbonate (161 mg, $0.8 \mathrm{mmol}, 10 \mathrm{eq})$ and bipyridine $(298 \mathrm{mg}$, $1.9 \mathrm{mmol}, 25 \mathrm{eq})$. The crude product was purified by silica gel column chromatography (DCM and gradually ending with $\mathrm{DCM} / \mathrm{MeOH}$ 9/1). The compound $\mathbf{8 N i}$ (20 mg, $0.017 \mathrm{mmol}, 22 \%$ ) was obtained as a red solid. ${ }^{1} \mathrm{H}$ NMR (400 MHz, DMSO- $d_{6}$ ): $\delta 10.12(\mathrm{~d}, J=6.2 \mathrm{~Hz}$, $2 \mathrm{H}, \mathrm{H}$-ortho-py $\left.{ }^{+}\right), 9.24$ (d, J = 5.0 Hz, 2H, H- $\beta$-pyrrolic), $9.13(\mathrm{q}, J=5.0 \mathrm{~Hz}, 4 \mathrm{H}, \mathrm{H}-\beta$-pyrrolic), $9.03(\mathrm{~m}, 4 \mathrm{H}$, $\mathrm{H}$ - $\beta$-pyrrolic and H-ortho-py), $8.96(\mathrm{~d}, J=6.2 \mathrm{~Hz}, 2 \mathrm{H}$, H-meta-pyr $\left.{ }^{+}\right), 8.34(\mathrm{~d}, J=4.6 \mathrm{~Hz}, 2 \mathrm{H}, \mathrm{H}-m e t a-p y r)$, 8.02-7.81 (m, 6H, H-ortho-Tol and H-meta-Anisol), 7.58 (d, $J=7.6 \mathrm{~Hz}, 4 \mathrm{H}, \mathrm{H}-m e t a-\mathrm{Tol}), 7.30$ (d, $J=8.1 \mathrm{~Hz}, 2 \mathrm{H}$, $\mathrm{H}$-ortho-Anisol), 4.05 (s, 3H, -OMe), 2.66 (s, 6H, - $\mathrm{CH}_{3}$ ). ${ }^{13} \mathrm{C}$ NMR $\left(126 \mathrm{MHz}, \mathrm{DMSO}-d_{6}\right)$ : $\delta 166.4,161.5,157.9$, $151.9,151.6,149.9,144.3,139.6,138.2,136.0,134.8$, $133.3,132.6,131.5,128.9,127.3,125.7,124.1,123.3$, 117.9, 113.7, 56.0, 21.4. UV-vis $\left(\mathrm{CHCl}_{3}\right): \lambda(\varepsilon)=416$ (89000), 532 (9200), $563 \mathrm{~nm}\left(5000 \mathrm{M}^{-1} \cdot \mathrm{cm}^{-1}\right)$. MALDITOF: $m / z=807.265$. Calcd for $\mathrm{C}_{51} \mathrm{H}_{37} \mathrm{~N}_{6} \mathrm{Ni}^{+}\left(\left[\mathrm{M}^{+}\right]\right)$: 807.24. TLC (silica) $R_{f}: 0.15$ (DCM/MeOH 9/1).

Zn-Porph-biPy ${ }^{+}$(8Zn). Prepared following the procedure for GP1 and using tris(4-bromophenyl)ammoniumyl hexachloroantimonate ( $73 \mathrm{mg}, 0.09 \mathrm{mmol}, 1.2 \mathrm{eq})$, 10-(4-methoxyphenyl)-5,15-di-p-tolylporphyrin-zinc (50 mg, $0.076 \mathrm{mmol}, 1 \mathrm{eq}$ ), cesium carbonate (161 mg, $0.76 \mathrm{mmol}, 10 \mathrm{eq}$ ) and bipyridine (296 mg, $1.9 \mathrm{mmol}$, $25 \mathrm{eq})$. The crude product was purified by silica gel column chromatography (DCM and gradually ending with DCM/MeOH 9/1). The compound 8Zn (11 mg, $0.01 \mathrm{mmol}, 18 \%$ ) was obtained as a green solid. ${ }^{1} \mathrm{H}$ NMR $\left(400 \mathrm{MHz}, \mathrm{CDCl}_{3}, 50^{\circ} \mathrm{C}\right): \delta 9.85(\mathrm{~d}, J=4.3 \mathrm{~Hz}, 2 \mathrm{H}$,

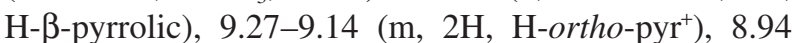
(d, $J=4.3 \mathrm{~Hz}, 2 \mathrm{H}, \mathrm{H}-\beta$-pyrrolic), 8.89-8.78 (m, 4H, $\mathrm{H}-\beta$-pyrrolic $+\mathrm{H}$-meta-pyr $\left.{ }^{+}\right), 8.59(\mathrm{~d}, J=4.3 \mathrm{~Hz}, 2 \mathrm{H}$, H- $\beta$-pyrrolic), 8.31-8.19 (m, 2H, H-meta-pyr $\left.{ }^{+}\right), 7.92$ (d, $J=8.5 \mathrm{~Hz}, 2 \mathrm{H}, \mathrm{H}$-ortho-Anisol), $7.84(\mathrm{~d}, J=7.7 \mathrm{~Hz}$, 4H, H-ortho-Tol), 7.65 (d, J=4.2 Hz, 2H, H-ortho-pyr ${ }^{+}$), 7.49 (d, $J=7.7 \mathrm{~Hz}, 4 \mathrm{H}, \mathrm{H}-m e t a-T o l), 7.23$ (d, $J=8.5 \mathrm{~Hz}$, $2 \mathrm{H}, \mathrm{H}-m e t a-A n i s o l), 4.07\left(\mathrm{~s}, 3 \mathrm{H},-\mathrm{OCH}_{3}\right), 2.65(\mathrm{~s}$, $\left.6 \mathrm{H},-\mathrm{CH}_{3}\right) .{ }^{13} \mathrm{C}$ NMR $\left(126 \mathrm{MHz}, \mathrm{DMSO}-d_{6}\right): \delta 159.5$, $155.1,151.6,151.1,151.0,150.5,146.2,144.7,139.4$, $138.0,137.6,135.7,134.7,134.5,134.4,133.4,132.7$, $132.1,128.5,127.9,125.9,124.2,123.0,122.9,121.7$, $117.5,112.7,55.8,21.5,21.2$. UV-vis $\left(\mathrm{CHCl}_{3}\right): \lambda(\varepsilon)=$ 429 (584800), 561 (42400), $611 \mathrm{~nm}\left(18000 \mathrm{M}^{-1} \cdot \mathrm{cm}^{-1}\right)$. 
1 ESI-TOF: $m / z=813.23$. Calcd for $\mathrm{C}_{51} \mathrm{H}_{37} \mathrm{~N}_{6} \mathrm{Zn}^{+}\left(\left[\mathrm{M}^{+}\right]\right)$: 2 813.24. TLC (silica) $R_{f}: 0.19$ (DCM/MeOH 9/1).

Ni-Porph-bisPy ${ }^{+}$(9Ni). Prepared following the procedure for GP1 and using tris(4-bromophenyl)ammoniumyl hexachloroantimonate $(36 \mathrm{mg}, 0.048 \mathrm{mmol}$, 1.2 eq), 10-(4-methoxyphenyl)-5,15-di-p-tolylporphyrinnickel (25 mg, $0.04 \mathrm{mmol}, 1 \mathrm{eq})$, cesium carbonate ( $80 \mathrm{mg}$, $0.4 \mathrm{mmol}, 10 \mathrm{eq})$ and 1,3-bis(pyridin-3-ylethynyl) benzene $(112 \mathrm{mg}, 0.4 \mathrm{mmol}, 10 \mathrm{eq})$. The crude product was purified by silica gel column chromatography (DCM and gradually ending with DCM/MeOH 9/1). The compound $9 \mathrm{Ni}$ (9 mg, $0.007 \mathrm{mmol}, 17 \%$ ) was obtained as a red solid. ${ }^{1} \mathrm{H}$ NMR $\left(400 \mathrm{MHz}, \mathrm{CDCl}_{3}\right): \delta 9.54(\mathrm{~d}$, $\left.J=5.8 \mathrm{~Hz}, 1 \mathrm{H}, \mathrm{H}-\mathrm{py}^{+}\right), 9.40\left(\mathrm{~s}, 1 \mathrm{H}, \mathrm{H}-\mathrm{py}^{+}\right), 9.22$ (d, $J=$ $5.0 \mathrm{~Hz}, 2 \mathrm{H}, \mathrm{H}-\beta$-pyrrolic), $9.14\left(\mathrm{~d}, J=5.8 \mathrm{~Hz}, 1 \mathrm{H}, \mathrm{H}_{-} \mathrm{py}^{+}\right)$, 9.09 (s, 4H, H- $\beta$-pyrrolic), 8.88 (br, 1H, , H-py), 8.74 (d, $J=5.0 \mathrm{~Hz}, 2 \mathrm{H}, \mathrm{H}-\beta$-pyrrolic), 8.68 (br, 2H, H-pyr ${ }^{+}$and H-pyr), 7.90 (d, $J=8.2 \mathrm{~Hz}, 2 \mathrm{H}, \mathrm{H}$-ortho-Anisol), 7.84 (d, $J=7.7 \mathrm{~Hz}, 4 \mathrm{H}, \mathrm{H}$-ortho-Tol), 7.80 (d, $J=7.9 \mathrm{~Hz}$, 8H), 7.72-7.70 (m, 1H, H-pyr), 7.69-7.62 (m, 2H, H-pyr and $\mathrm{H}$-aryl), 7.51 (m, 2H, H-aryl), 7.46 (d, $J=7.7 \mathrm{~Hz}$, 4H, H-ortho-Tol), 7.40-7.31 (m, 1H, Haryl), 7.23 (d, $J=$ $8.2 \mathrm{~Hz}, 2 \mathrm{H}$, H-ortho-Anisol), 4.04 (s, 3H, $-\mathrm{OCH}_{3}$ ), 2.61 $\left(\mathrm{s}, 6 \mathrm{H},-\mathrm{CH}_{3}\right) .{ }^{13} \mathrm{C} \mathrm{NMR}\left(126 \mathrm{MHz}, \mathrm{DMSO}-d_{6}\right): \delta 159.9$, $152.3,152.3,152.0,151.1,150.4,150.0,149.9,149.8$, $149.6,146.0,143.1,142.2,141.7,139.1,138.3,136.4$, $135.3,135.1,134.0,133.6,132.7,132.5,131.6,130.3$, $128.5,127.6,124.2,123.1,123.0,123.0,122.9,122.1$, 121.5, 119.4, 118.1, 113.3, 95.8, 91.2, 87.8, 84.3, 55.9, 21.5. UV-vis $\left(\mathrm{CHCl}_{3}\right): \lambda(\varepsilon)=419$ (69000), 533 (6900), $564 \mathrm{~nm}\left(3800 \mathrm{M}^{-1} \cdot \mathrm{cm}^{-1}\right)$. ESI-TOF: $\mathrm{m} / z=931.27$. Calcd for $\mathrm{C}_{61} \mathrm{H}_{41} \mathrm{~N}_{6} \mathrm{NiO}^{+}\left(\left[\mathrm{M}^{+}\right]\right): 931.27$. TLC (silica) $R_{f}: 0.15$ (DCM/MeOH 9/1).

Zn-Porph-Py $\left.{ }^{+} \quad \mathbf{1 0 Z n}\right)$. Prepared following the procedure for GP1 and using tris(4-bromophenyl) ammoniumyl hexachloroantimonate $(88 \mathrm{mg}, 0.11 \mathrm{mmol}$, 1.2 eq), 5,15-di-p-tolylporphyrin-zinc $(50 \mathrm{mg}, 0.09$ mmol, $1 \mathrm{eq})$, and pyridine $(711 \mathrm{mg}, 9.0 \mathrm{mmol}, 726 \mu \mathrm{L}$, 100 eq). The crude product was purified by silica gel column chromatography (DCM and gradually ending with DCM/MeOH 9/1). The compound 10Zn (18 mg, $0.023 \mathrm{mmol}, 26 \%$ ) was obtained as a purple solid after recrystallization (addition of saturated $\mathrm{KPF}_{6}$ aqueous solution to acetone solution). ${ }^{1} \mathrm{H}$ NMR (400 MHz, DMSO- $d_{6}$ ): $\delta 10.56$ (s, $1 \mathrm{H}, \mathrm{H}-$ meso $), 10.27$ (d, $J=6.2 \mathrm{~Hz}$, $2 \mathrm{H}, \mathrm{H}$-ortho-pyr ${ }^{+}$), 9.59 (d, $J=4.5 \mathrm{~Hz}, 2 \mathrm{H}, \mathrm{H}-\beta$-pyrrolic), 9.30 (dd, $J=7.8,6.2 \mathrm{~Hz}, 1 \mathrm{H}, \mathrm{H}-$ para-pyr $\left.{ }^{+}\right), 8.98-8.95$ (m, 4H, H- $\beta$-pyrrolic), 8.70 (d, $J=4.5 \mathrm{~Hz}, 2 \mathrm{H}, \mathrm{H}-\beta$ pyrrolic), 8.64 (dd, $J=7.8,6.2 \mathrm{~Hz}, 2 \mathrm{H}, \mathrm{H}-m e t a-$ pyr $^{+}$), 8.08 (d, $J=7.7 \mathrm{~Hz}, 4 \mathrm{H}, \mathrm{H}$-ortho-Tol), 7.66 (d, $J=7.7 \mathrm{~Hz}$, $4 \mathrm{H}, \mathrm{H}-$ meta-Tol), $2.70\left(\mathrm{~s}, 6 \mathrm{H},-\mathrm{CH}_{3}\right) \cdot{ }^{13} \mathrm{C} \mathrm{NMR}(126$ $\left.\mathrm{MHz}, \mathrm{DMSO}-d_{6}\right): \delta 150.8,150.3,150.1,149.8,149.6$, $148.2,145.1,138.8,137.1,134.3,134.0,133.5,132.6$, $127.5,127.2,126.4,121.8,117.6,109.3,54.9,21.1 .{ }^{31} \mathrm{P}$ NMR (121 MHz, DMSO- $\left.d_{6}\right): \delta-141.2(\mathrm{q}, J=708 \mathrm{~Hz})$. ${ }^{19} \mathrm{~F}$ NMR $\left(282 \mathrm{MHz}, \mathrm{DMSO}-d_{6}\right): \delta-70.1(\mathrm{~d}, J=708 \mathrm{~Hz})$. UV-vis $\left(\mathrm{CHCl}_{3}\right): \lambda(\varepsilon)=311$ (5000), 422 (64000), 553
(4000), $599 \mathrm{~nm}\left(1500 \mathrm{M}^{-1} \cdot \mathrm{cm}^{-1}\right)$. ESI-TOF: $m / z=630.17$ Calcd for $\mathrm{C}_{39} \mathrm{H}_{28} \mathrm{~N}_{5} \mathrm{Zn}^{+}\left(\left[\mathrm{M}^{+}\right]\right)$: 630.16. TLC $R_{f}: 0.28$ (DCM/MeOH 9/1).

\section{Acknowledgments}

The authors are grateful to the University of Strasbourg and the CNRS for financial support. RL thanks the Fondation Recherche en Chimie (ic-FRC) and the Région Grand-Est for a joined $\mathrm{PhD}$ fellowship.

\section{Supporting information}

Spectral data for the examined compounds are given in the supplementary material. This material is available free of charge via the Internet at http://www.worldscinet. com/jpp/jpp.shtml.

\section{REFERENCES}

1. Osuka A and Shimidzu H. Angew. Chem., Int. Ed. 1997; 36: 135-137.

2. Aratani N, Takagi A, Yanagawa Y, Matsumoto T, Kawai T, Yoon Z S, Kim D and Osuka, A. Chem. Eur. J. 2005; 11: 3389-3404.

3. Ogawa T, Nishimoto Y, Yoshida N, Ono N and Osuka A. Angew. Chem., Int. Ed. 1999; 38: 176-179.

4. (a) Evans B and Smith KM. Tetrahedron Lett. 1977; 35: 3079-3082. (b) Smith KM, Barnett GH, Evans B and Martynenko Z. J. Am. Chem. Soc. 1979; 10: 5953-5961.

5. Giraudeau A, Ruhlmann L, El Kahef L and Gross M. J. Am. Chem. Soc. 1996; 118: 2969-2979.

6. Ruhlmann L, Lobstein S, Gross M and Giraudeau A. J. Org. Chem. 1999; 64: 1352-1355.

7. (a) Ruhlmann L and Giraudeau A. J. Chem. Soc., Chem. Commun. 1996; 2007-2008. (b) Ruhlmann L and Giraudeau A. Eur. J. Inorg. Chem. 2001; 659-668.

8. (a) Huo Z, Gisselbrecht JP, Farha R, Goldmann M, Saint-Aman E, Bucher C and Ruhlmann L. Electrochim. Acta 2014; 122: 108-117. (b) Azcarate I, Huo Z, Farha R, Goldmann M, Xu H, Hasenknopf B, Lacôte L and Ruhlmann L. Chem. - Eur. J. 2015; 21: 8271-8280. (c) Schaming D, Allain C, Farha R, Goldmann M, Lobstein S, Giraudeau A, Hasenknopf B and Ruhlmann L. Langmuir 2010; 26: 5101-5109.

9. Berthelot M, Hoffmann G, Bousfiha A, Echaubard J, Roger J, Cattey H, Romieu A, Lucas D, FleuratLessard P and Devillers CH. Chem. Commun. 2018; 54: 5414-5417.

10. For an in-depth comparison of both methods see: Connelly NG and Geiger WE. Chem. Rev. 1996; 96: 877-910.

11. (a) Xia Y, Schaming D, Farha R, Goldmann M and Ruhlmann L. New. J. Chem. 2012; 36: 588-596; 
(b) Schaming D, Xia Y, Thouvenot R, Ruhlmann L. Chem. - Eur. J. 2013; 19: 1712-1719.

12. Øpstad CL, Melø TB, Sliwka HR and Partali V. Tetrahedron 2009; 65: 7616-7619.

13. Dime AKD, Devillers CH, Cattey H and Lucas D. Dalton Trans. 2014; 43: 14554-14564.

14. Dime AKD, Devillers CH, Cattey H, Habermeyer B and Lucas D. Dalton Trans. 2012; 41: 929-936.

15. Manka JS and Lawrence DS. Tetrahedron Lett. 1989; 30: 6989-6992.

16. Takanami T, Hayashi M, Chijimatsu H, Inoue W and Suda K. Org. Lett. 2005; 7: 3937-3940.

17. Habermeyer B, Takai A, Gros CP, El Ojaimi M, Barbe JM and Fukuzumi S. Chem. - Eur. J. 2011; 17: 10670-10681.

18. Brückner C, Posakony JJ, Johnson CK, Boyle RW, James BR and Dolphin D. J. Porphyrins Phthalocyanines 1998; 2: 455-465.
19. Senge MO, Shaker YM, Pintea M, Ryppa C, Hatscher SS, Ryan A and Sergeeva Y. Eur. J. Org. Chem. 2011; 1: 77-80.

20. Salzl S, Ertl M and Knör G. Phys. Chem. Chem. Phys., 2017; 19: 8141-8147.

21. Boudiaf M, Liang Y, Lamare R, Weiss J, Ibrahim H, Goldmann M, Bentouhami E, Badets V, Choua S, Le Breton N, Bonnefont A and Ruhlmann L. Electrochim. Acta, 2019; 309: 432-449.

22. Buchler JW, Eikelmann G, Puppe L, Rohbock K, Schneehage HH and Weck D. Liebigs Ann. Chem. 71; 745: 135-151.

23. Stolzenberg M and Shussel LJ. Inorg. Chem. 1991; 30: 733-738. 